Article

\title{
Performance of Reverse Osmosis Membranes in the Treatment of Flue-Gas Desulfurization (FGD) Wastewaters
}

\author{
Carmela Conidi $^{1}$, Francesca Macedonio ${ }^{1, *}$, Pietro Argurio ${ }^{2}{ }^{(0)}$, Alfredo Cassano ${ }^{1, *}$ (i) and \\ Enrico Drioli ${ }^{1}$ (10) \\ 1 Institute on Membrane Technology, ITM-CNR, c/o University of Calabria, via P. Bucci, 17/C, \\ I-87036 Rende, Italy; c.conidi@itm.cnr.it (C.C.); e.drioli@itm.cnr.it (E.D.) \\ 2 Department of Environmental \& Chemical Engineering, University of Calabria, Via P. Bucci, 44/A, \\ I-87036 Rende, Italy; pietro.argurio@unical.it \\ * Correspondence: f.macedonio@itm.cnr.it (F.M.); a.cassano@itm.cnr.it (A.C.)
}

Received: 28 May 2018; Accepted: 17 June 2018; Published: 19 June 2018

\begin{abstract}
Reverse osmosis (RO) was studied to reduce salinity of flue gas desulfurization (FGD) wastewaters after softening with $\mathrm{Na}_{2} \mathrm{CO}_{3} \cdot \mathrm{H}_{2} \mathrm{O}$ and ultrafiltration (UF). Two commercial thin film composite polyamide RO membranes (SWC-2540 and ESPA-2540, from Hydranautics) in spiral-wound configuration were tested and their performance in terms of salinity reduction as well as permeate flux, fouling index and water recovery was evaluated. Experimental runs were performed according to the feed and bleed configuration in selected operating conditions. For the SWC-2540 membrane experiments were also performed in total recycle configuration in order to evaluate the effect of operating pressure on permeate flux and quality. Experimental results indicated that the SWC-2540 membrane showed a better performance in the rejection of ions: $\mathrm{Mg}^{2+}$ ions were completely rejected, while the rejection towards monovalent ions such as $\mathrm{Na}^{+}$was of about $95.5 \%$. The ESPA-2540 membrane showed rejections towards $\mathrm{Ca}^{2+}$ and $\mathrm{Mg}^{2+}$ higher than $86.5 \%$ whilst the observed rejection towards $\mathrm{Na}^{+}$was of $80 \%$. For the SWC-2540 membrane an increased rejection for $\mathrm{Ca}^{2+}$ and $\mathrm{Na}^{+}$ions was observed by increasing the operating pressure in the range 16-50 bar. $\mathrm{Mg}^{2+}$ ions were totally rejected independently by the operating pressure.
\end{abstract}

Keywords: flue gas desulfurization wastewaters; reverse osmosis; desalination; membrane systems; environmental protection

\section{Introduction}

The combustion of coal in power generation facilities produces solid waste, such as bottom and fly ash, and flue gas that is emitted to the atmosphere. The sulfur dioxide reduction from the exhausted flue gas of fossil fuel thermoelectric power plants is accomplished through wet scrubber technologies according to a process known as flue gas desulfurization (FGD). Wet scrubbers typically remove more than $90 \%$ of sulfur dioxide, compared to dry scrubbers, which remove only $80 \%$. These processes generate a polluted wastewater with an extremely complex composition depending on coal source, type of scrubber, makeup water quality, gypsum-dewatering system used and operational conditions.

Typically, FGD wastewaters contain significantly high concentration of chloride, sulfate, nitrate, calcium and magnesium and trace-levels of heavy metals, such as $\mathrm{Hg}$ (II), $\mathrm{Pb}$ (II), $\mathrm{Cd}$ (II), Mn(II) and $\mathrm{Ni}(\mathrm{II})$. Total dissolved solids (TDS) are in the range 4000-50,000 mg/L, while suspended solids range from $1.4 \%$ to $17 \%$ [1].

Discharge of FGD wastewaters without sufficient treatment pose serious environmental issues because of its detrimental impact on human health and ecological system. In this scenario, according 
to the European Directive 2000/60/CE, the use of regenerated water takes a key role in conferring utmost protection to water. In addition, the use of regenerated wastewater for irrigation purposes offer very interesting perspectives in terms of both environmental and economic impact.

Biological processes [2-4], flocculation [5], adsorption [6], constructed wetland [7], evaporation [8], chemical precipitation [9] and electrocoagulation [10] are typically used to remove heavy metal ions, nitrate or soluble organic contaminants from FGD wastewater. These methods do not meet standard regulations, especially for the high salinity of the FGD wastewaters. In addition, they are significantly constrained by process complexity, large investment, high maintenance cost, operating difficulties and other shortcomings and limitations. Therefore, advanced treatments based on the selective removal of various trace contaminants from such a complex matrix, are one of the biggest challenges for thermal power plants.

Membrane technologies are a high potential option in order to attempt the complete depuration of FGD wastewaters due to their advantages over conventional separations systems such as compact modular nature, high efficiency and moderate investment and maintenance costs. These processes are becoming increasingly used in the recent years in the purification of water and groundwater, in replacement of many conventional separation processes, as well as in the reclamation of several wastewater streams. In particular, pressure-driven membrane operations such as microfiltration (MF), ultrafiltration (UF), nanofiltration (NF) and reverse osmosis (RO) have been increasingly implemented in the recent years in the purification of groundwater and surface water as well as for decontamination of wastewater streams of very diverse sources [11,12]. Among pressure-driven membrane operations, $\mathrm{RO}$ represents a valid approach for treating wastewater with high conductivity. It is generally used to remove water pollutants, such as phosphorus, organic matter as well as in desalination processes, in order to remove, for example, $\mathrm{Na}^{+}$and $\mathrm{Cl}^{-}$[13].

Few studies have been reported until now on the use of membrane operations in the treatment of FGD wastewaters. For instance, polyvinylidene fluoride (PVDF) microfiltration (MF) membranes in hollow fiber configuration have been used to remove $\mathrm{Hg}$ after chemical precipitation from FGD wastewaters providing a simple, reliable, long-term and cost economic solution for the reduction of mercury compounds in these wastewaters [14]. An integrated process based on the use of nanofiltration (NF) and membrane distillation (MD) processes for practical application in FGD wastewater treatment has been also recently investigated by Jia and Wang [15]. The whole system exhibited nearly complete salt rejection and over $92 \%$ water reclamation ratio.

This work was aimed at evaluating the performance of commercial reverse osmosis (RO) membranes, in terms of salinity reduction as well as permeate flux, fouling index and water recovery, in the treatment of softened and ultrafiltered flue-gas desulfurization (FGD) wastewaters.

\section{Materials and Methods}

\subsection{Softening and Pre-Treatment Processes of FGD Wastewaters}

FGD wastewaters were provided by IER (Industrial Enel Research, Brindisi, Italy). Before use, they were submitted to a chemical pre-treatment in order to remove the amount of inorganic compounds (in particular calcium and magnesium) that can cause scaling issue during $\mathrm{RO}$ treatment, reducing membrane performance. In particular, FGD wastewaters were softened with $\mathrm{Na}_{2} \mathrm{CO}_{3} \cdot \mathrm{H}_{2} \mathrm{O}$ $(>97 \%$, Carlo Erba Reagenti, Milan, Italy) in order to reduce the quantity of calcium and magnesium. A preliminary set of experiments was performed to select the appropriate amount of alkalizing agents in order to achieve maximum removal efficiencies. At this purpose, the effect of $\mathrm{Na}_{2} \mathrm{CO}_{3} \cdot \mathrm{H}_{2} \mathrm{O} / \mathrm{Ca}^{2+}$ molar ratio on the removal of calcium was studied in a fixed volume of FGD wastewaters at a temperature of $25^{\circ} \mathrm{C}$. The solutions were incubated for $1 \mathrm{~h}$ to let the majority of the solids particles settle out and then ultrafiltered before acidification with $\mathrm{H}_{2} \mathrm{SO}_{4}$ up to $\mathrm{pH}$ 6.5.

Ultrafiltration (UF) was performed by using a laboratory unit (Verind SpA, Milan, Italy) equipped with a polyethersulfone hollow fiber membrane module supplied by Microdyn-Nadir (Wiesbaden, 
Germany) having a nominal molecular weight cut-off (MWCO) of $500 \mathrm{kDa}$ and an effective membrane area of $0.25 \mathrm{~m}^{2}$. UF was operated according to a feed-and-bleed configuration (the permeate is removed from the system and replaced by an equal volume of feed solution while the retentate stream is recycled back to the feed reservoir) at a transmembrane pressure (TMP) of 0.5 bar, an axial feed flow rate $\left(\mathrm{Q}_{\mathrm{f}}\right)$ of $500 \mathrm{~L} / \mathrm{h}$ and a temperature (T) of $25 \pm 2{ }^{\circ} \mathrm{C}$, up to a recovery factor (RF) of $97.5 \%$.

\subsection{Treatment of Permeate UF by RO: Experimental Set-Up and Membranes}

RO experimental runs were performed by using a laboratory plant supplied by Matrix Desalination Inc. (Fort Lauderdale, FL, USA). The equipment consists of a feed tank with a capacity of $10 \mathrm{~L}$, a stainless steel housing for $2.4 \times 21$ inches spiral-wound membrane module, a high pressure pump, two pressure gauges (0-100 bar) for the control of the inlet and outlet pressures and a backpressure valve. A coiling cool, fed with tap water, was used to maintain the feed temperature constant.

Two commercial spiral wounds RO membranes in composite polyamide namely SWC-2540 and ESPA-2540 from Hydranautics (Hydranautics Corporation, Oceanside, CA, USA) were studied. Properties of the selected membranes, are summarized in Table 1. Experimental runs were performed according to the feed and bleed configuration in selected operating conditions (TMP 26 bar, $Q_{f} 204 \mathrm{~L} / \mathrm{h}$, $\mathrm{T} 20^{\circ} \mathrm{C}$ for the SWC membrane and TMP $18 \mathrm{bar}, \mathrm{Q}_{\mathrm{f}} 220 \mathrm{~L} / \mathrm{h}, \mathrm{T} 20^{\circ} \mathrm{C}$ for the ESPA 2540 membrane) up to a RF of 50\%, corresponding to a weight reduction factor (WRF) of 2. The ESPA-2540 membrane was tested at lower TMP values, according to the manufacturer's data sheet.

Table 1. Characteristics of spiral-wound membrane modules.

\begin{tabular}{ccc}
\hline Membrane Type & SWC-2540 & ESPA-2540 \\
\hline Manufacturer & Hydranautics & Hydranautics \\
Membrane material & Composite polyamide & Composite polyamide \\
Salt rejection $(\%)$ & 99.4 (minimum 99$)$ & 99.4 (minimum 98) \\
pH operating range & $2-11$ & $2-10$ \\
Max. operating temperature $\left({ }^{\circ} \mathrm{C}\right)$ & 45 & 45 \\
Max. operating pressure $(\mathrm{bar})$ & 69 & 21 \\
Membrane surface area $\left(\mathrm{m}^{2}\right)$ & 2.34 & 2.34 \\
Water permeability $\left(\mathrm{kg} / \mathrm{m}^{2} \mathrm{hbar}\right)$ & $1.77^{\mathrm{a}}$ & $5.90^{\mathrm{a}}$ \\
${\text { Contact angle }\left({ }^{\circ}\right)}_{\text {Zeta potential }(\mathrm{mV})}$ & $58.9 \pm 1.2^{\mathrm{b}}$ & $34.0 \pm 2.00^{\mathrm{c}}$ \\
\hline${ }^{\mathrm{a}}$ our data; $^{\mathrm{b}}$ data from $[16]^{\circ}{ }^{\mathrm{c}}$ data from $[17]^{\mathrm{d}}{ }^{\mathrm{d}}$ data from $[18]^{\mathrm{e}}{ }^{\mathrm{e}}$ data from $[19]$.
\end{tabular}

For the SWC-2540 membrane experiments were also performed in total recycle configuration (in which concentrate and permeate streams were both recycled back to the feed tank) in order to evaluate the effect of TMP on the permeate flux and quality of the obtained permeate. Experiments were performed in the range of TMP values between 16 and 50 bar (at $T$ of $25^{\circ} \mathrm{C}$ and $\mathrm{Q}_{\mathrm{f}}$ of $240 \mathrm{~L} / \mathrm{h}$ ), so as to generate a steady-state flux (about $40 \mathrm{~min}$ for each TMP value). When flux values were stable, permeate samples were collected to determine the rejection coefficients.

After each experiment, membranes were rinsed with water and then cleaned with an acid solution (Ultraclean WO $0.05 \%, \mathrm{pH} 4$ ) at $40{ }^{\circ} \mathrm{C}$, for $60 \mathrm{~min}$, in total recycle configuration. At the end of each cleaning procedure membrane modules were rinsed with distilled water for $20 \mathrm{~min}$ and the water permeability was measured again. 


\subsection{Permeate Fluxes, Hydraulic Permeability, Fouling Index and Cleaning Efficiency}

During the filtration experiments the permeate flux was continuously monitored by measuring the permeate weight collected in a certain time according to the following equation:

$$
J_{p}=\frac{W_{p}}{A t}
$$

where $J_{p}$ is the permeate flux $\left(\mathrm{kg} / \mathrm{m}^{2} \mathrm{~h}\right), W_{p}$ the permeate weight $(\mathrm{kg})$ at time $t(\mathrm{~h})$ and $A$ the membrane surface area $\left(\mathrm{m}^{2}\right)$.

The hydraulic permeability $\left(W_{p}\right)$ of each membrane was determined by the slope of the straight line obtained plotting the water flux values, measured in fixed conditions of temperature $\left(25^{\circ} \mathrm{C}\right)$, versus the applied TMP.

The fouling index (FI), expressed as a percentage drop in the water permeability, was estimated by measuring the water permeability before and after the treatment of FGD wastewaters, according to the following equation:

$$
F I=\left(1-\frac{W_{p 1}}{W_{p 0}}\right) \times 100
$$

where $W_{p 0}$ and $W_{p 1}$ are the pure water permeability before and after FGD wastewaters treatment.

The cleaning efficiency $(C E)$ was evaluated according to the following equation:

$$
C E=\left(\frac{W_{p 2}}{W_{p 0}}\right) \times 100
$$

where $W_{p 2}$ is the water permeability measured after the chemical cleaning.

\subsection{Analytical Methods}

pH was measured by an Orion Expandable ion analyzer EA 920 pH meter (Allometrics, Inc., Baton Rouge, LA, USA) with automatic temperature compensation. Electrical conductivity (ED) and total dissolved solids (TDS) were measured using a digital conductivity meter (HI 2300 Microprocessor Conductivity, Hanna Instruments, Woonsocket, RI, USA). Concentration of the main cations $\left(\mathrm{Ca}^{2+}\right.$, $\mathrm{Mg}^{2+}$ and $\mathrm{Na}^{+}$) was determined by using a high-resolution continuum source atomic absorption spectrometer (HR-CSAAS, ContrAA700, Analytik Jena AG, Jena, Germany), with a high intensity Xe short arc lamp as continuum source. Samples and standards were fed to the flame by an Injection Module (SFS6), which allowed washing or continuous aspiration of the carrier solution. They were appropriately diluted (300 times for $\mathrm{Mg}$ and $\mathrm{Ca}, 3000$ times for $\mathrm{Na}$ ). Subsequently they were acidified with $1 \% \mathrm{HCl}$. Method parameters (i.e., fuel flow and burner height) obtained by the flame automatic optimization procedure for the determination of $\mathrm{Ca}^{2+}\left(\mathrm{N}_{2} \mathrm{O} /\right.$ acetylene flame) and $\mathrm{Na}^{+}$or $\mathrm{Mg}^{2+}$ (air-acetylene flame) were applied, the absorbance measurements being performed using the spectral lines for Ca at $422.67 \mathrm{~nm}$, for $\mathrm{Na}$ at 588.99 and for $\mathrm{Mg}$ at $285.21 \mathrm{~nm}$.

The removal efficiency for each analyzed component was determined during membrane processes and quantified as percentage rejection $(\mathrm{R})$ of a particular component:

$$
R=\left(1-\frac{C p}{C f}\right) \cdot 100
$$

where $c_{f}$ and $c_{p}$ are the component concentrations in the feed and permeate, respectively. 


\section{Results and Discussion}

\subsection{Pre-Treatment Processes}

The appropriate dose of $\mathrm{Na}_{2} \mathrm{CO}_{3} \cdot \mathrm{H}_{2} \mathrm{O}$ for an efficient softening process was investigated experimentally. Sodium carbonate promotes the removal of $\mathrm{Ca}^{2+}$ ions through reactive precipitation as $\mathrm{CaCO}_{3}$. Therefore, the proper $\mathrm{Na}_{2} \mathrm{CO}_{3}$ addition was determined with respect to the $\mathrm{Ca}^{2+}$ ion concentration in the FGD wastewaters to be treated. The obtained results (Figure 1) prove that $\mathrm{Ca}^{2+}$ and $\mathrm{Mg}^{2+}$ removal efficiency increased by growing the coagulant dosage until $\mathrm{Na}_{2} \mathrm{CO}_{3} \cdot \mathrm{H}_{2} \mathrm{O} / \mathrm{Ca}^{2+}$ molar ratio between 2.27 and 3.18, then a plateau is reached. In particular, in this range the removal of $\mathrm{Ca}^{2+}$ achieved up to $90 \%$, whilst the removal of $\mathrm{Mg}^{2+}$, at the same coagulant dosage, was of about $30 \%$. The $\mathrm{pH}$ of the FGD wastewaters increased from 9.2 to 10.6 in the range of investigated $\mathrm{Na}_{2} \mathrm{CO}_{3} \cdot \mathrm{H}_{2} \mathrm{O} / \mathrm{Ca}^{2+}$ molar ratio due to the increased release of $\mathrm{OH}^{-}$ions in the solution.

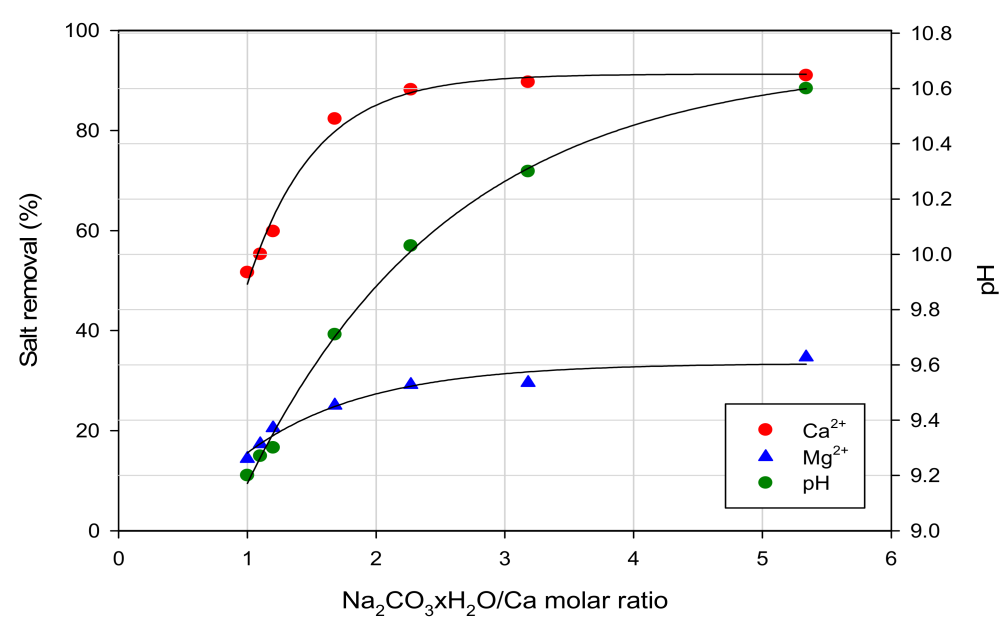

Figure 1. Effect of $\mathrm{Na}_{2} \mathrm{CO}_{3} \cdot \mathrm{H}_{2} \mathrm{O} /$ Calcium molar ratio on salt removal and $\mathrm{pH}$.

Ayoub et al. [20] investigated the removal of inorganic compounds (including calcium and magnesium) in seawater using $\mathrm{Na}_{2} \mathrm{CO}_{3}$ as alkalizing agents and obtained similar results. In particular, the removal efficiencies recorded were of $90 \pm 2.5 \%$ for $\mathrm{Ca}^{2+}$ and $15 \pm 4.55 \%$ for $\mathrm{Mg}^{2+}$. A similar $\mathrm{Ca}^{2+}$ removal efficiency (higher than 90\%) was observed also by Zheng et al. [21] during the treatment of textile and dyeing wastewaters using $\mathrm{NaOH}$. Based on these experimental results, an average $\mathrm{Na}_{2} \mathrm{CO}_{3} \cdot \mathrm{H}_{2} \mathrm{O} / \mathrm{Ca}^{2+}$ molar ratio of 2.6 was chosen for performing the softening.

Before RO, softened FGD wastewaters were preliminary submitted to a UF process. In the selected operating conditions steady-state UF permeate fluxes of about $480 \mathrm{~kg} / \mathrm{m}^{2} \mathrm{~h}$ were obtained. The composition of FGD wastewaters before and after the chemical and the UF treatments is reported in Table 2. As expected, in the optimized $\mathrm{Na}_{2} \mathrm{CO}_{3} \cdot \mathrm{H}_{2} \mathrm{O} / \mathrm{Ca}^{2+}$ molar ratio conditions a higher removal of $\mathrm{Mg}^{2+}$ and $\mathrm{Ca}^{2+}$ was obtained whilst, the removal of other analyzed compounds was lower (in the range $11-27 \%$ ). The UF process, allowed to remove more than $60 \%$ of TOC, while the content of inorganic compounds and TDS remained unchanged in agreement with the MWCO of the selected UF membrane.

Table 2. Composition of flue gas desulfurization (FGD) wastewaters before and after pre-treatment processes (EC, electrical conductivity; TDS, total dissolved solids; TC, total carbon; TOC, total organic carbon; IC, inorganic carbon).

\begin{tabular}{ccccccccc}
\hline Sample & $\begin{array}{c}\mathbf{C a}^{2+} \\
(\mathbf{p p m})\end{array}$ & $\begin{array}{c}\mathbf{M g}^{2+} \\
\mathbf{( p p m )}\end{array}$ & $\begin{array}{c}\mathbf{N a}^{+} \\
\mathbf{( g / L )}\end{array}$ & $\begin{array}{c}\mathbf{E C} \\
(\mathbf{m S} / \mathbf{c m})\end{array}$ & $\begin{array}{c}\text { TDS } \\
\mathbf{( g / L )}\end{array}$ & $\begin{array}{c}\text { TC } \\
(\mathbf{m g} / \mathbf{L})\end{array}$ & $\begin{array}{c}\text { TOC } \\
(\mathbf{m g} / \mathbf{L})\end{array}$ & $\begin{array}{c}\mathbf{I C} \\
(\mathbf{m g} / \mathbf{L})\end{array}$ \\
\hline FGD wastewater & $384.4 \pm 4.8$ & $289.4 \pm 2.6$ & $7.2 \pm 0.6$ & $33.6 \pm 2.1$ & $16.9 \pm 0.6$ & - & - & - \\
After softening & $83.8 \pm 0.5$ & $174.7 \pm 1.2$ & $6.4 \pm 0.8$ & $25.08 \pm 1.6$ & $12.46 \pm 1.8$ & $90.96 \pm 0.91$ & $90.12 \pm 0.90$ & $0.57 \pm 0.05$ \\
After ultrafiltration & $82.0 \pm 1.6$ & $171.8 \pm 3.4$ & $6.3 \pm 0.12$ & $25.8 \pm 0.5$ & $12.5 \pm 0.2$ & $82.98 \pm 0.83$ & $33.80 \pm 0.34$ & $49.18 \pm 0.49$ \\
\hline
\end{tabular}




\section{2. $R O$ of Pre-Treated FGD Wastewaters}

Figure 2 shows the time evolution of permeate flux for both RO membranes in the treatment of the softened and ultrafiltered FGD wastewater, in the selected operating conditions. Despite different operating TMP values, $\mathrm{RO}$ membranes showed similar initial permeate fluxes values (of about $14 \mathrm{~kg} / \mathrm{m}^{2} \mathrm{~h}$ ). The permeate flux declined rapidly in the first $30 \mathrm{~min}$; then the rate of flux decline became slower and a pseudo-steady state flux of $2.3 \mathrm{~kg} / \mathrm{m}^{2} \mathrm{~h}$ and $1.9 \mathrm{~kg} / \mathrm{m}^{2} \mathrm{~h}$ for the ESPA and SWC membranes respectively, was reached. This behavior has to be attributed to the increase of the osmotic pressure of feed solution due to the high salt rejection of the selected membranes, and to the concentration polarization and membrane fouling phenomena. This leads to a severe driving force decrease and, consequently, to a flux decline [22]. In particular, the observed flux decline of selected membranes was in the range of $84-86 \%$.

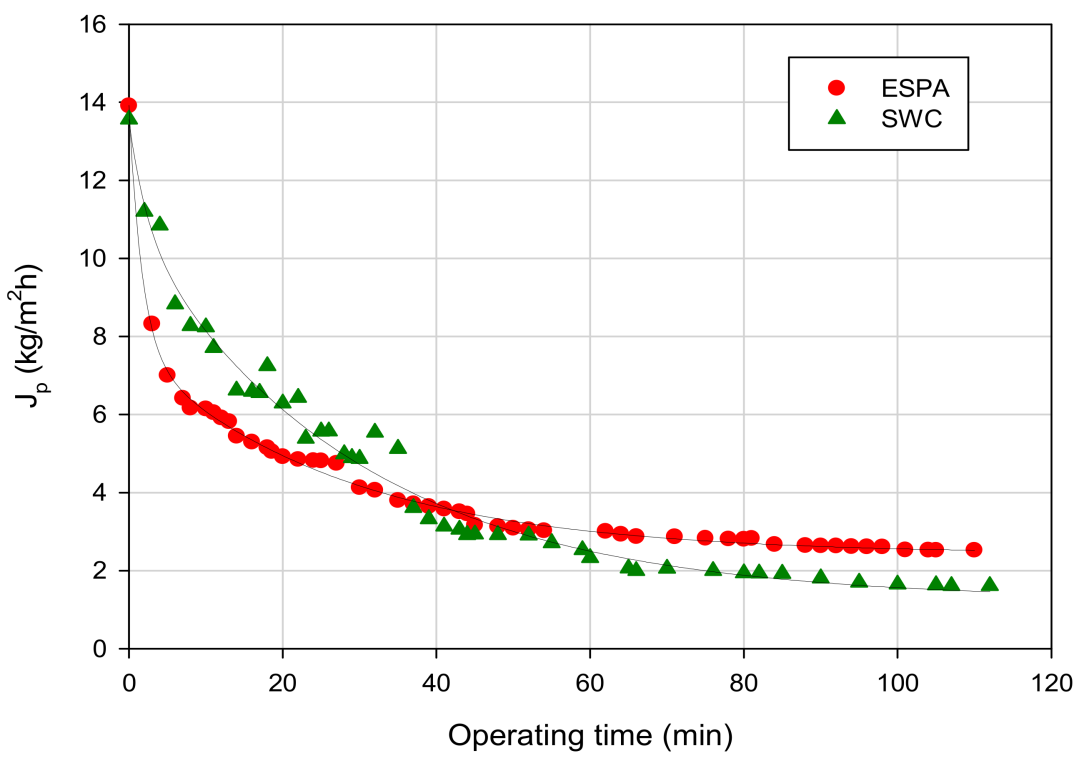

Figure 2. Reverse osmosis (RO) of pre-treated flue gas desulfurization (FGD) wastewaters with selected membranes. Time course of permeate flux. $\left(\mathrm{T}, 20^{\circ} \mathrm{C} ; \mathrm{Q}_{\mathrm{f}}, 220 \mathrm{~L} / \mathrm{h}\right.$; recovery factor $\left.(\mathrm{RF}), 50 \%\right)$.

A similar permeate flux decline was observed by Vourch et al. [23] in the treatment of dairy industry wastewaters for water reuse, with a RO spiral wound membrane (TFC HR SW 2540) in thin film composite, having a $\mathrm{NaCl}$ rejection of the same order (99.5\%).

Dolar et al. [24] obtained a permeate flux decline of about $72 \%$ during processing of pre-treated landfill leachate with a RO (XLE) membrane from Dow/Filmtec (Midland, MI, USA).

A street correlation between the concentration of feed solution and permeate flux decline was reported by Tang et al. [25] in the processing of semiconductor wastewaters with a RO ESPA membrane. They obtained a reduction of permeate flux of $10 \%$ at a concentration of feed solution of $10 \mathrm{ppm}$ of perfluorooctane sulphonate (PFOS) and of about $60 \%$ at $500 \mathrm{ppm}$ of PFOS. Authors attributed the flux decline with the entrapment of PFOS molecules in the polyamide layer and their accumulation on the membrane surfaces.

Table 3 shows the fouling index for the selected membranes based on their water permeability before and after the pre-treated FGD wastewaters filtration. According to the obtained values, the ESPA membrane showed a lower fouling index (FI, 28.8\%) in comparison with the SWC membrane (FI, 35.3\%). This behavior could be attributed to the different morphology (surface roughness) and contact angles of selected membranes (Table 1). As reported in literature, membranes with smooth and hydrophilic surfaces (as the ESPA) presented less fouling tendency than those with rough and hydrophobic surfaces (as the SWC) [26]. 
Table 3. Hydraulic permeability measurement and fouling index of reverse osmosis (RO) membranes $\left(W_{p 0}\right.$, initial water permeability; $W_{p 1}$, after the treatment with FGD wastewaters; $W_{p 2}$, after cleaning with water at $30^{\circ} \mathrm{C} ; W_{p 3}$, after acid cleaning at $\left.\mathrm{pH} 4\right)$.

\begin{tabular}{lcc}
\hline \multirow{2}{*}{ Parameter } & \multicolumn{2}{c}{ Membrane Type } \\
\cline { 2 - 3 } & SWC-2540 & ESPA-2540 \\
\hline$W_{p 0}(\mathrm{~kg} / \mathrm{m} 2 \mathrm{hbar})$ & 1.7 & 5.9 \\
$W_{p 1}(\mathrm{~kg} / \mathrm{m} 2 \mathrm{hbar})$ & 1.1 & 4.2 \\
$W_{p 2}(\mathrm{~kg} / \mathrm{m} 2 \mathrm{hbar})$ & 1.6 & 5.2 \\
$W_{p 3}(\mathrm{~kg} / \mathrm{m} 2 \mathrm{hbar})$ & 1.7 & 5.4 \\
Fouling index (FI) $(\%)$ & 35.3 & 28.8 \\
Cleaning efficiency (CE) (\%) & 100.0 & 92.0 \\
\hline
\end{tabular}

After cleaning with water, the water permeability of both membranes was lower than $10 \%$ when compared to the initial one. After chemical cleaning, a complete recovery of the initial water permeability was observed for the SWC-2540 membrane and of about $92 \%$ for the ESPA 2540 membrane. The low fouling index measured for both membranes and the almost complete recovery of RO membranes performance could be attributed to the pre-treatment processes (softening, precipitation and ultrafiltration) that limited inorganic scaling and the possible deposition of inorganic substances on membrane surface or inside the membrane pores [26].

The selected membranes were also compared in terms of permeate quality and removal of salt compounds. The chemical composition of permeate and retentate fractions produced with both $\mathrm{RO}$ membranes, at a WRF 2, is reported in Table 4.

Table 4. Chemical composition of FGD wastewaters before and after RO treatment.

\begin{tabular}{ccccccc}
\hline $\begin{array}{c}\text { Membrane } \\
\text { Type }\end{array}$ & Sample & $\begin{array}{c}\mathbf{C a}^{2+} \\
(\mathbf{p p m})\end{array}$ & $\begin{array}{c}\mathbf{M g}^{2+} \\
(\mathbf{p p m})\end{array}$ & $\begin{array}{c}\mathbf{N a}^{+} \\
(\mathbf{g} / \mathbf{L})\end{array}$ & $\begin{array}{c}\mathbf{E C} \\
(\mathbf{m S} / \mathbf{c m})\end{array}$ & $\begin{array}{c}\text { TDS } \\
(\mathbf{g} / \mathbf{L})\end{array}$ \\
\hline \multirow{3}{*}{ SWC-2540 } & Feed & $83.5 \pm 1.7$ & $178.4 \pm 3.5$ & $6.4 \pm 0.1$ & $26.1 \pm 0.52$ & $12.6 \pm 0.25$ \\
& Permeate & $11.0 \pm 0.2$ & n.d. & $0.29 \pm 0.01$ & $1.76 \pm 0.03$ & $0.87 \pm 0.01$ \\
& Retentate & $159.2 \pm 3.4$ & $362.2 \pm 7.8$ & $12.52 \pm 0.26$ & $49.3 \pm 1.0$ & $24.6 \pm 0.5$ \\
\hline \multirow{3}{*}{ ESPA-2540 } & Feed & $52.1 \pm 1.03$ & $196.2 \pm 3.9$ & $6.4 \pm 0.1$ & $25.1 \pm 0.5$ & $13.9 \pm 0.3$ \\
& Permeate & $6.75 \pm 0.13$ & $6.8 \pm 0.13$ & $1.25 \pm 0.02$ & $3.6 \pm 0.2$ & $1.8 \pm 0.04$ \\
& Retentate & $98.6 \pm 2.2$ & $383.6 \pm 7.8$ & $11.5 \pm 0.25$ & $45.6 \pm 2.3$ & $22.8 \pm 0.7$ \\
\hline
\end{tabular}

The electrical conductivity rejection for ESPA-2540 and SWC-2540 membranes, were of about $85.7 \%$ and $93.2 \%$, respectively (Figure 3). The TDS rejection of the SWC-2540 membrane was relatively higher $(93 \%)$ if compared with the ESPA-2540 membrane (87\%). In addition, the SWC-2540 membrane showed a better performance in the rejection of ions. $\mathrm{Mg}^{2+}$ ions were completely rejected by the SWC-2540 membrane ( $\mathrm{R}$ of $100 \%$ ), while the rejection towards monovalent ions such as $\mathrm{Na}^{+}$was lower ( $\mathrm{R}$ of about $95.5 \%$ ). The ESPA-2540 membrane showed rejections towards $\mathrm{Ca}^{2+}$ and $\mathrm{Mg}^{2+}$ higher than $86.5 \%$; on the other hand, the observed rejection towards $\mathrm{Na}^{+}$was of $80 \%$. Considering that divalent ions are larger than monovalent ions, the main mechanism of ion rejection by RO membranes is size exclusion [27]. However, the charges of ions and membranes employed cannot be neglected since they also interact each other electrostatically. At the pH of FGD wastewaters (6.5) both membranes are negatively charged $[18,19]$. Therefore, electrostatic attraction forces between the negatively charged membrane surface and specific ions can contribute to the retention mechanism. 


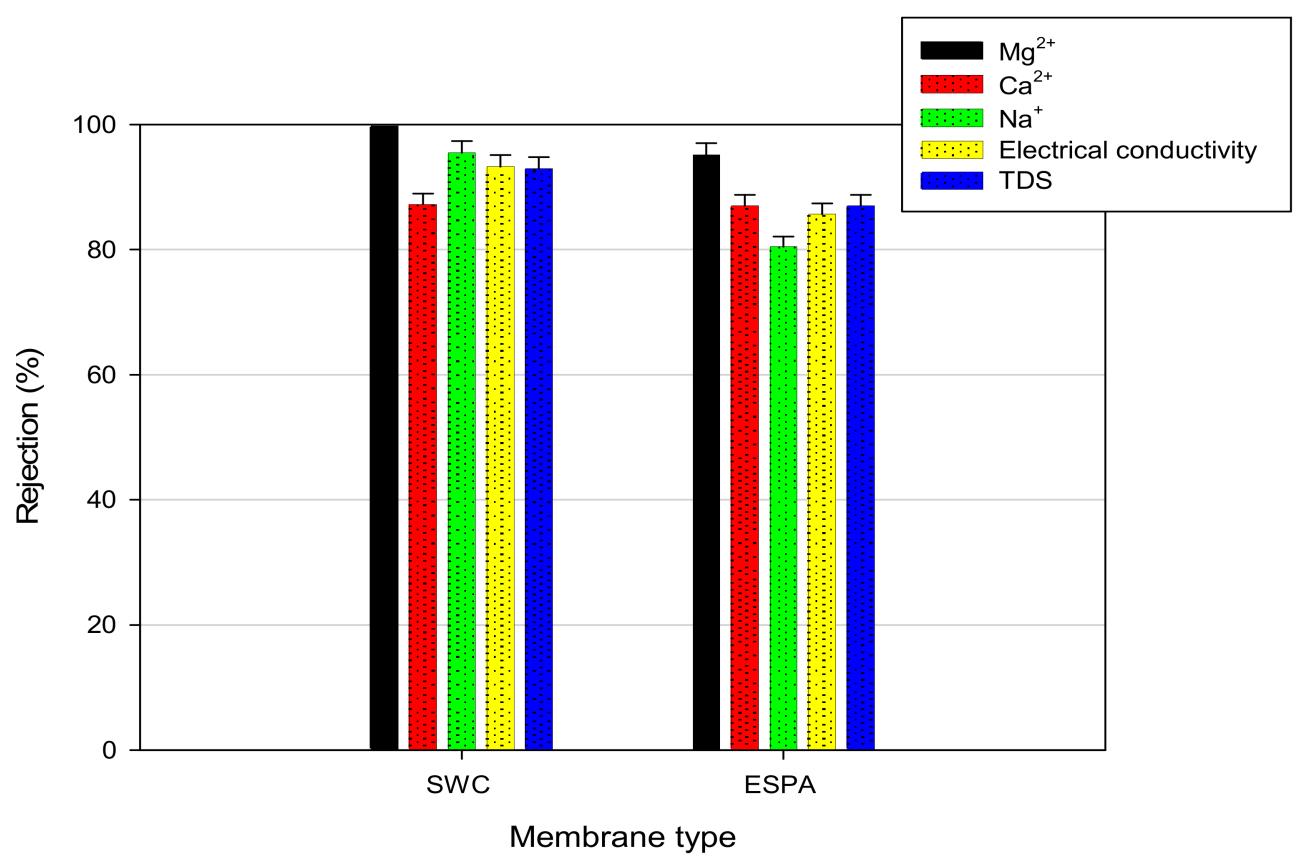

Figure 3. Rejection of RO membranes towards ions, electrical conductivity (EC) and total dissolved solids (TDS).

In Tables 5 and 6 the mass balance of the RO process for both investigated membranes is reported. The balance is referred to RO experimental runs in which starting from $18 \mathrm{~L}$ of pre-treated FGD wastewaters, $9 \mathrm{~L}$ of permeate and $9 \mathrm{~L}$ of retentate were obtained. It can be noted that for both $\mathrm{RO}$ membranes, the main ions are mainly concentrated in the retentate streams; on the other hand, the amount in the permeate is lower than $10 \%$. The balance is complete, indicating that no interaction ions-membranes, or adsorption of ions on the membranes surface, occurs during the process.

Table 5. Mass balance of the RO process for the SWC-2540 membrane.

\begin{tabular}{ccccccc}
\hline Parameter & Feed & \multicolumn{2}{c}{ Permeate } & \multicolumn{2}{c}{ Retentate } & Balance \\
\hline Volume & $18 \mathrm{~L}$ & $9 \mathrm{~L}$ & $50.0 \%$ & $9 \mathrm{~L}$ & $50.0 \%$ & $100.0 \%$ \\
$\mathrm{Ca}^{2+}$ & $1503 \mathrm{mg}$ & $99.0 \mathrm{mg}$ & $6.5 \%$ & $1432.8 \mathrm{mg}$ & $95.3 \%$ & $101.8 \%$ \\
$\mathrm{Mg}^{2+}$ & $3211.2 \mathrm{mg}$ & $0 \mathrm{mg}$ & $0.0 \%$ & $3259.8 \mathrm{~g}$ & $101.5 \%$ & $101.5 \%$ \\
$\mathrm{Na}^{+}$ & $115.2 \mathrm{mg}$ & $2.6 \mathrm{mg}$ & $2.2 \%$ & $112.7 \mathrm{~g}$ & $97.8 \%$ & $100.0 \%$ \\
\hline
\end{tabular}

Table 6. Mass balance of the RO process for the ESPA-2540 membrane.

\begin{tabular}{ccccccc}
\hline Parameter & Feed & \multicolumn{2}{c}{ Permeate } & \multicolumn{2}{c}{ Retentate } & Balance \\
\hline Volume & $18 \mathrm{~L}$ & $9 \mathrm{~L}$ & $50.0 \%$ & $9 \mathrm{~L}$ & $50.0 \%$ & $100.0 \%$ \\
$\mathrm{Ca}^{2+}$ & $937.8 \mathrm{mg}$ & $60.7 \mathrm{mg}$ & $6.5 \%$ & $887.4 \mathrm{mg}$ & $94.6 \%$ & $101.1 \%$ \\
$\mathrm{Mg}^{2+}$ & $3531.6 \mathrm{mg}$ & $61.2 \mathrm{mg}$ & $1.7 \%$ & $3452.4 \mathrm{~g}$ & $97.7 \%$ & $99.4 \%$ \\
$\mathrm{Na}^{+}$ & $115.2 \mathrm{mg}$ & $11.2 \mathrm{mg}$ & $9.7 \%$ & $103.5 \mathrm{~g}$ & $89.9 \%$ & $99.6 \%$ \\
\hline
\end{tabular}

According to the obtained results, the SWC-2540 membrane exhibited the highest removal efficiency for all measured parameters. Therefore, the quality of the produced permeate was higher if compared with the permeate produced by ESPA-2540 membrane. The SWC-2540 permeate presented an electrical conductivity lower than $2 \mathrm{mS} / \mathrm{cm}$; it resulted completely depleted of bivalent ions such as $\mathrm{Mg}^{2+}$, with a low amount of total dissolved solids (TDS) $(<1 \mathrm{~g} / \mathrm{L})$ and $\mathrm{Ca}^{2+}$. 


\subsection{Experiments in Total Recycle Mode}

For the SWC-2540 membrane experiments were also performed according to the total recycle configuration in order to evaluate the effect of TMP on the permeate flux and the removal efficiency of salt compounds. Figure 4 shows the time evolution of the permeate flux at different TMP values (increased in the range 16-50 bar) and fixed values of temperature and feed flowrate $\left(25^{\circ} \mathrm{C}\right.$ and $240 \mathrm{~L} / \mathrm{h}$, respectively). An increase of initial and steady-state permeate fluxes from $0.86 \mathrm{~kg} / \mathrm{m}^{2} \mathrm{~h}$ to $16.8 \mathrm{~kg} / \mathrm{m}^{2} \mathrm{~h}$ and from $0.61 \mathrm{~kg} / \mathrm{m}^{2} \mathrm{~h}$ to $10.4 \mathrm{~kg} / \mathrm{m}^{2} \mathrm{~h}$, respectively, was observed by increasing the operating pressure in the range of investigated values.

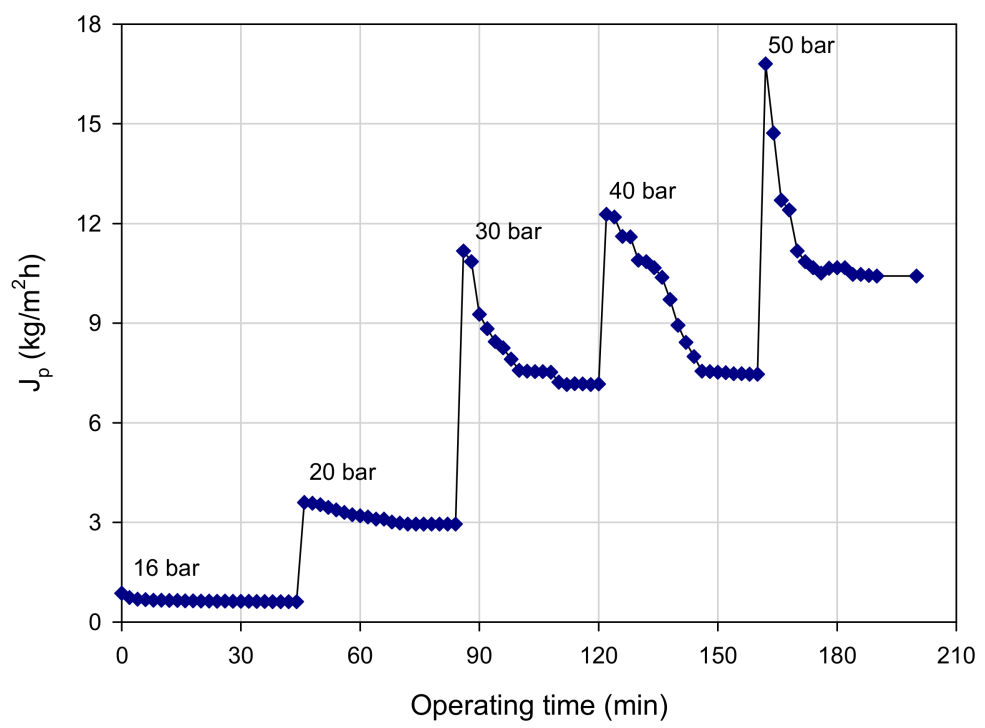

Figure 4. RO of pre-treated FGD wastewaters with SWC-2540 membrane. Permeate flux as function of transmembrane pressure (TMP) $\left(\mathrm{T}, 25^{\circ} \mathrm{C} ; \mathrm{Q}_{\mathrm{f}}, 240 \mathrm{~L} / \mathrm{h}\right)$.

Mohammadi et al. [28] reported a linear increase of permeate flux with pressure in the treatment of seawater with a polyamide FT30 RO membrane. A linear trend between permeate flux and pressure was also observed by Mondal and Wickramasinghe [29] in the treatment of oily wastewaters with a BW 30 membrane (FilmTec Corporation, Minneapolis, MN, USA) in aromatic polyamide with a $\mathrm{NaCl}$ rejection of $99.4 \%$.

A different behavior was reported by Liu et al. [30] in the treatment of textile effluents for water reuse with the same membrane (BW30). In this case, a decrease of permeate fluxes by increasing the operating pressure, was observed.

From Figure 4 it is also possible to note that working at high pressure values (higher than 20 bar) there is an increase of the permeate flux decline by increasing the operating time. As previously discussed, this behavior could be attributed to membrane fouling and concentration polarization phenomena. Particularly, working at high pressure, concentration polarisation is known to be the main factor that contributes to the increasing salt concentration at the membrane surface hence leading to particle deposition and an increasing of scaling [31].

In Figure 5 the effect of TMP on the rejection towards main ions and other analyzed compounds, is showed. It can be noted that the rejection of $\mathrm{Mg}^{2+}$ was not affected by TMP: indeed, the rejection was of $100 \%$ independently by the applied pressure. Adversely, an increase of rejection by increasing the operating pressure was observed for $\mathrm{Ca}^{2+}$ and $\mathrm{Na}^{+}$. In particular, the rejection for $\mathrm{Ca}^{2+}$ and $\mathrm{Na}^{+}$ increased from $32.3 \%$ and $82.2 \%$ at TMP of 16 bar to $78 \%$ and $98 \%$ at TMP of 50 bar, respectively. A similar trend was observed for TDS rejection. Similar results, in terms of TDS rejection, were observed by Nataraj et al. [32] in the removal of dye and salts from simulated wastewaters with a TFC polyamide $\mathrm{RO}$ membrane in spiral-wound configuration. 


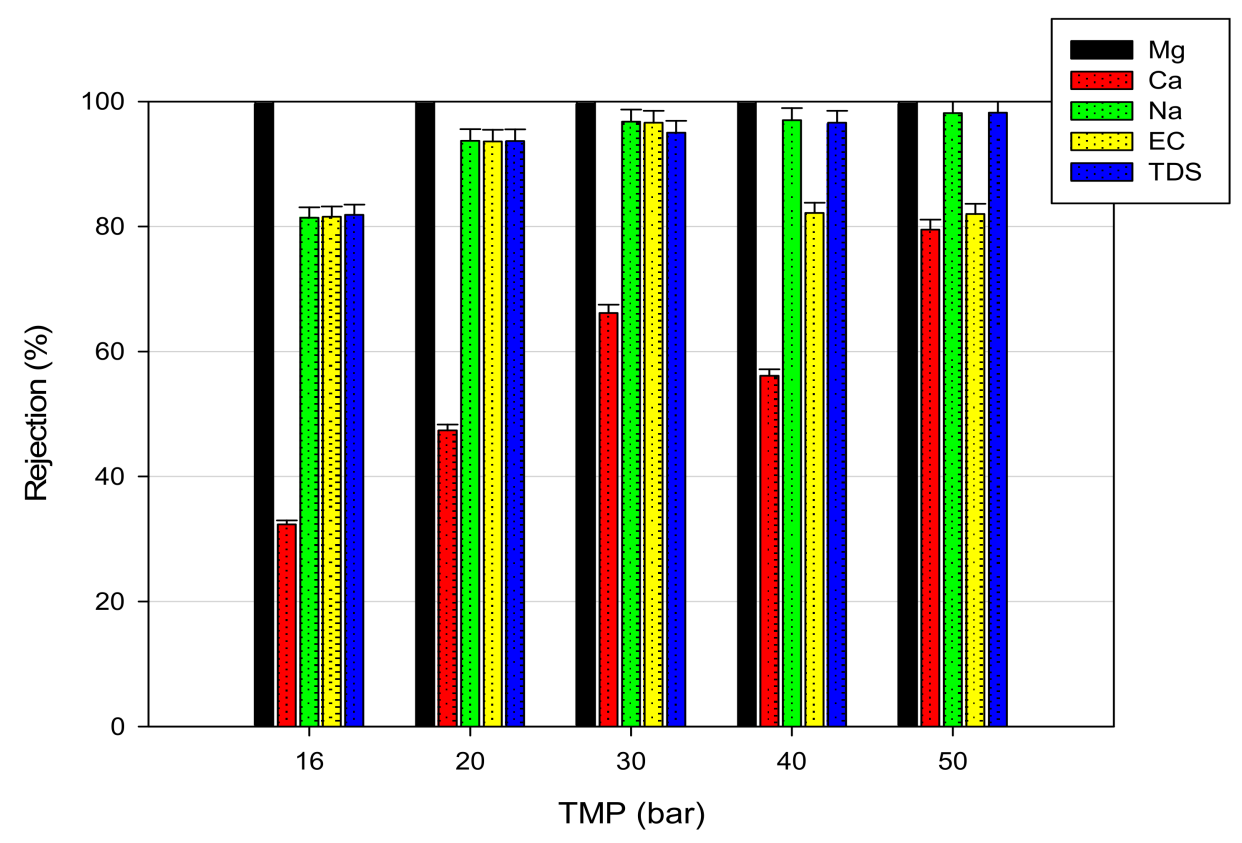

Figure 5. Rejection of SWC membrane towards ions, electrical conductivity (EC) and total dissolved solids (TDS) at different TMP values.

The increase of the rejections by increasing the TMP could be attributed to the increase of solvent flux at higher pressure, resulting in the decreasing of salts concentration and ions in the permeate. On the other hand, during the RO treatment more components (ions and salts) are transported from the bulk solution towards the membrane surface as permeate flux increases, which enhance concentration polarization and consequently the faster flux decline (from the initial to the steady-state values) at the increasing of TMP.

\section{Conclusions}

Reverse osmosis (RO) was studied to reduce the saline content of softened and ultrafiltered flue gas desulfurization (FGD) wastewaters. Commercial spiral-wound RO membranes (named SWC and ESPA) were tested on laboratory scale and compared for their performance in terms of productivity, salt rejections, fouling index and cleaning efficiency.

The SWC membrane was effective in reducing more than $85 \%$ of $\mathrm{Na}^{+}, \mathrm{Ca}^{2+}$ and $\mathrm{Mg}^{2+}$ ions in selected operating conditions with low fouling index and higher cleaning efficiency in comparison to the ESPA membrane. Retention values for $\mathrm{Na}^{+}$and $\mathrm{Ca}^{2+}$ ions increased by increasing the operating pressure, whilst $\mathrm{Mg}^{2+}$ ions were totally rejected independently by the transmembrane pressure.

Further investigations will be devoted to the combination of $\mathrm{RO}$ with membrane distillation in order to process the RO brine for the production of high purity water (which can be reused in thermal power plant) and salts (when membrane distillation is operated as membrane distillation/crystallization). The integrated system might allow exploiting the added value of RO brine, extracting water and crystals, thus approaching zero-liquid discharge strategy.

Author Contributions: E.D. supervised the technical activities and the paper writing. A.C. and F.M. conceived and designed the experiments (softening and membrane treatment of FGD wastewaters). Lab scale experiments of softening and membrane processing of FGD wastewaters were performed by C.C. She was also involved in the analytical characterization of feed, pretreated, permeate and retentate samples with technical contribution of P.A. All Authors contributed to the interpretation and discussion of experimental results.

Funding: This work was performed within the Project "Materials Technologies for performance improvement of Cooling Systems in Power Plants" (MATChING) which received funding from the European Union's Horizon 2020 research and innovation program under the grant agreement number 686031.

Conflicts of Interest: The authors declare no conflict of interest. 


\section{References}

1. USEPA. Steam Electric Power Generating Point Source Category: Final Detailed Study Report. EPA 821-R-09-08; 2009. Available online: https://www.epa.gov/sites/production/files/2015-06/ documents/steam-electric_detailed_study_report_2009.pdf (accessed on 26 April 2018).

2. Pickett, T.; Sonstegard, J.; Bonkoski, B. Using biology to treat selenium. Power Eng. 2008, 110, $140-145$.

3. Wei, C.; He, W.J.; Wei, L.; Ma, J.; Li, C.Y. The performance and microbial communities of biodegradation-electron transfer with sulfur metabolism integrated process for flue gas desulfurization wastewater treatment. Bioprocess. Biosyst. Eng. 2017, 40, 1543-1553. [CrossRef] [PubMed]

4. Zhang, L.; Lin, X.J.; Wang, J.T.; Jiang, F.; Wei, L.; Chen, G.H.; Hao, X.D. Effects of lead and mercury on sulfate-reducing bacterial activity in a biological process for flue gas desulfurization wastewater treatment. Sci. Rep. 2016, 6, 30455. [CrossRef] [PubMed]

5. Wu, Z.B.; Ni, W.M.; Guan, B.H. Application of chitosan as flocculant for coprecipitation of Mn(II) and suspended solids from dual-alkali FGD regenerating process. J. Hazard. Mater. 2008, 152, 757-764. [CrossRef] [PubMed]

6. Huang, Y.H.; Peddi, P.K.; Tang, C.L.; Zeng, H.; Teng, X.J. Hybrid zero-valent iron process for removing heavy metals and nitrate from flue-gas-desulfurization wastewater. Sep. Purif. Technol. 2013, 118, 690-698. [CrossRef]

7. Sundberg-Jones, S.E.; Hassan, S.M. Macrophyte sorption and bioconcentration of elements in a pilot constructed wetland for flue gas desulfurization wastewater treatment. Water Air Soil Pollut. 2007, 183, 187-200. [CrossRef]

8. Ma, S.C.; Chai, J.; Chen, G.D.; Yu, W.J.; Zhu, S.J. Research on desulfurization wastewater evaporation: Present and future perspectives. Renew. Sustain. Energy Rev. 2016, 58, 1143-1151.

9. Yu, J.; Lu, J.; Kang, Y. Removal of sulfate from wet FGD wastewater by co-precipitation with calcium hydroxide and sodium aluminate. Water Sci. Technol. 2018, 77, 1336-1345. [CrossRef] [PubMed]

10. Liu, S.N.; Ye, X.K.; He, K.; Chen, Y.C.; Hu, Y.Y. Simultaneous removal of Ni(II) and fluoride from a real flue gas desulfurization wastewater by electrocoagulation using Fe/C/Al electrode. J. Water Reuse Desalin. 2017, 7, 288-297. [CrossRef]

11. López, J.; Coello, M.D.; Quiroga, J.M. Comparative studies of reverse osmosis membranes for wastewater reclamation. Desalination 2006, 191, 137-147. [CrossRef]

12. Van der Bruggen, B.; Vandecasteele, C. Removal of pollutants from surface water and groundwater by nanofiltration: Overview of possible applications in the drinking water industry. Environ. Pollut. 2003, 122, 435-445. [CrossRef]

13. Malaeb, L.; Ayoub, G.M. Reverse osmosis technology for water treatment: State of the art review. Desalination 2011, 267, 1-8. [CrossRef]

14. Liu, C.; Farooq, K.; Doll, B.; Venkatadri, R. Economical and reliable mercury reduction in refinery and power plant discharge wastewater with robust microfiltration membrane technology. Desalin. Water Treat. 2013, 51, 4980-4986. [CrossRef]

15. Jia, F.; Wang, J. Treatment of flue gas desulfurization wastewater with near-zero liquid discharge by nanofiltration-membrane distillation process. Sep. Sci. Technol. 2018, 53, 146-153. [CrossRef]

16. Li, Q.; Song, J.; Yu, H.; Li, Z.K.; Pan, X.H.; Yang, B. Investigating the microstructures and surface features of seawater $\mathrm{RO}$ membranes and the dependencies of fouling resistance performances. Desalination 2014, 352, 109-117. [CrossRef]

17. Dražević, E.; Košutić, K.; Fingler, S.; Drevenkar, V. Removal of pesticides from the water and their adsorption on the reverse osmosis membranes of defined porous structure. Desalin. Water Treat. 2011, 30, 161-170. [CrossRef]

18. Lee, S.; Lee, E.; Elimelech, M.; Hong, S. Membrane characterization by dynamic hysteresis: Measurements, mechanisms, and implications for membrane fouling. J. Membr. Sci. 2011, 366, 17-24. [CrossRef]

19. Ishida, K.P.; Bold, R.; Phipps, D.W. Identification and Evaluation of Unique Chemicals for Optimum Membrane Compatibility and Improved Cleaning Efficiency; Technical Report April; Orange County Water District: Fountain Valley, CA, USA, 2005.

20. Ayoub, G.M.; Zayyar, R.M.; Al-Hindi, M. Precipitation softening: A pre-treatment process for seawater desalination. Environ. Sci. Pollut. Res. 2014, 21, 2876-2887. [CrossRef] [PubMed] 
21. Zheng, L.; Wang, X.; Wang, X. Reuse of reverse osmosis concentrate in textile and dyeing industry by combined process of persulfate oxidation and lime-soda softening. J. Clean. Prod. 2015, 108, 525-533. [CrossRef]

22. Teixeira, A.R.S.; Santos, J.L.C.; Crespo, J.C. Sustainable membrane-based process for valorization of cork boiling wastewaters. Sep. Purif. Technol. 2009, 66, 35-44. [CrossRef]

23. Vourch, M.; Balannec, B.; Chaufer, B.; Dorange, G. Treatment of dairy industry wastewater by reverse osmosis for water reuse. Desalination 2008, 219, 190-202. [CrossRef]

24. Dolar, D.; Košutić, K.; Strmecky, T. Hybrid processes for treatment of landfill leachate: Coagulation/UF/NF-RO and adsorption/UF/NF-RO. Sep. Purif. Technol. 2016, 168, 39-46. [CrossRef]

25. Tang, C.Y.; Fu, Q.S.; Robertson, A.P.; Criddle, C.; Leckie, J.O. Use of reverse osmosis to remove perfluorooctane sulfonate (PFOS) from semiconductor wastewater. Environ. Sci. Technol. 2006, 40, 7343-7349. [CrossRef] [PubMed]

26. Jiang, S.; Li, Y.; Ladewig, B.P. A review of reverse osmosis membrane fouling and control strategies. Sci. Total Environ. 2017, 595, 567-583. [CrossRef] [PubMed]

27. Sert, G.; Bunani, S.; Yörükoğlu, E.; Kabay, N.; Egemen, Ö.; Arda, M.; Yüksel, M. Performances of some NF and RO membranes for desalination of MBR treated wastewater. J. Water Proc. Eng. 2017, 16, 193-198. [CrossRef]

28. Mohammadi, T.; Moghadam, M.K.; Madaeni, S.S. Hydrodynamic factors affecting flux and fouling during reverse osmosis of seawater. Desalination 2002, 151, 239-245. [CrossRef]

29. Mondal, S.; Wickramasinghe, S.R. Produced water treatment by nanofiltration and reverse osmosis membranes. J. Membr. Sci. 2008, 322, 162-170. [CrossRef]

30. Liu, M.; Lü, Z.; Chen, Z.; Yu, S.; Gao, C. Comparison of reverse osmosis and nanofiltration membranes in the treatment of biologically treated textile effluent for water reuse. Desalination 2011, 281, 372-378. [CrossRef]

31. Goh, P.S.; Lau, W.J.; Othman, M.H.D.; Ismail, A.F. Membrane fouling in desalination and its mitigation strategies. Desalination 2018, 425, 130-155. [CrossRef]

32. Nataraj, S.K.; Hosamani, K.M.; Aminabhavi, T.M. Nanofiltration and reverse osmosis thin film composite membrane module for the removal of dye and salts from the simulated mixtures. Desalination 2009, 249, $12-17$. [CrossRef] 